\title{
Metabolic activity of Hordeum vulgare, Brassica napus and Vicia faba in Worm and Root type Biopore Sheaths
}

\author{
Lisa Petzoldt (D) Bärbel Kroschewski • \\ Timo Kautz
}

Received: 24 June 2021 / Accepted: 9 December 2021 / Published online: 5 January 2022

(C) The Author(s) 2021

\begin{abstract}
Aims Biopores offer favorable chemical, biological and physical properties for root growth in untilled soil layers. There they are considered as nutrient "hotspots" with preferential root growth. However, the literature lacks a quantification of metabolic activity due to nutrient acquisition of main crops while growing in the biopore sheath.

Methods A pot experiment was performed to map the metabolic activity of roots, as indicated by $\mathrm{pH}$ change. The roots of spring barley (Hordeum vulgare L.), spring oilseed rape (Brassica napus L.) and faba bean (Vicia faba L.) were growing through the biopore sheath influenced by an earthworm (Lumbricus terrestris L.) or a taproot (Cichorium intybus L.), in comparison to subsoil without a pore (bulk soil). $\mathrm{pH}$ sensitive planar optodes were applied in order to
\end{abstract}

Responsible Editor: Hans Lambers.

Supplementary Information The online version contains supplementary material available at https://doi. org/10.1007/s11104-021-05269-1.

L. Petzoldt $(\bowtie) \cdot$ B. Kroschewski · T. Kautz

Albrecht Daniel Thaer-Institute of Agri- and Horticultural

Science, Department of Crop Science, Humboldt-

Universität zu Berlin, Berlin, Germany

e-mail: lisa.petzoldt@hu-berlin.de

B. Kroschewski

Working group Biometry and Experimental Methods, Humboldt-Universität zu Berlin, Berlin, Germany image a planar section of the sheath, while preserving an intact biopore sheath during the experiment.

Results Roots were first found in the field of view in worm biopore then root biopore and bulk soil. At time of the first measurement the $\mathrm{pH}$ value was highest in worm biopore sheath (LS-Mean \pm SEM: 7.16a \pm 0.11 ), followed by root biopore sheath $(6.99 \mathrm{ab} \pm 0.12)$ and bulk soil $(6.61 \mathrm{~b} \pm 0.12)$. In spring oilseed rape a significant alkalization $(+0.80 \Delta \mathrm{pH})$ was found over time in bulk soil. Faba bean significantly acidified the root biopore sheath $(-0.73 \Delta \mathrm{pH})$. Spring barley showed no significant $\mathrm{pH}$ changes.

Conclusions The results of the current study reveal a trend of faster root growth through biopores and a higher initial $\mathrm{pH}$ value in the biopore sheaths compared to the bulk soil. Biopores serve not only as an elongation path for roots, but their sheaths also provide an environment for root activity in the subsoil.

Keywords biopore sheath - non-invasive imaging · $\mathrm{pH}$ planar optodes $\cdot$ metabolic activity $\cdot$ rhizosphere . root-soil interaction

\section{Introduction}

Biopores are continuous large pores that can be found in compacted soil and are mainly formed by roots and earthworms. Root growth and earthworm activity result in different chemical, biological (Tiunov and Scheu 1999; Uksa et al. 2015) and physical 
properties (Pagenkemper et al. 2015) of biopores and their sheath. Root growth in untilled deeper soil layers can be facilitated by physical access paths through biopores (Passioura 1991; Logsdon and Linden 1992). Biopore surroundings provide elevated nutrient concentrations, particularly in the first two millimeters of the sheath due to earthworm linings and root debris (Lavelle 1988; Athmann et al. 2017; Petzoldt et al. 2020). Generally, crops can respond to different nutrient availabilities in their root growing environment by changing their metabolic activity as reviewed by, e.g. Hinsinger et al. (2009), Hodge et al. (2009), Walter et al. (2009). Therefore it can be assumed, that the metabolic activities of the crop species differ in heterogeneous soil structures, such as worm or root type biopore sheaths and bulk soil, due to the specific environmental conditions.

Root growth in the biopore sheath in subsoil can be considered as relevant to overall nutrient acquisition, particularly in low input cropping systems. Substantial amounts of nutrients originate from subsoil, e.g. the subsoil contribution to the total $\mathrm{N}$ uptake of winter wheat was reported to be on average 33\% across 22 different sites, and even $75 \%$ when mineral fertilization to the topsoil was omitted (Kuhlmann et al. 1989). Athmann et al. (2016) showed in a ${ }^{15} \mathrm{~N}$ tracer field study that the quantity of $\mathrm{N}$ derived from the subsoil amounted to at least about $40 \%$ for mallow and $32 \%$ for wheat. Positive correlations were found between the number of biopores and $\mathrm{N}$ uptake of wheat (Volkmar 1996). However, it has not yet been demonstrated that roots growing through biopores effectively take up nutrients from the biopore sheath and that the inner layer of the biopore sheaths are truly relevant "hotspots" for nutrient acquisition. In fact, nutrient uptake from the biopore sheath can be limited by lack of root-soil contact and restricted root growth due to high bulk densities in the biopore sheath. Beneficial effects of biopores can also be based on provision of preferential pathways for root elongation and general facilitation of root growth.

It is well documented that plant roots respond to the environment they grow in, e.g. soil structure, nutrient availability, acidic or calcareous soils (Schubert et al. 1990) by actively altering the biochemical transfer in their rhizosphere (Hinsinger et al. 2003; Hinsinger et al. 2009; Hodge et al. 2009). In order to mobilize and forage on nutrients, the rhizosphere $\mathrm{pH}$ value varies along the root axis (Marschner et al.
1986). Hence, $\mathrm{pH}$ alterations can arise temporal and are dependent on root age and order (Hinsinger et al. 2009; Rudolph-Mohr et al. 2014). Besides this, heterogeneity in $\mathrm{pH}$ values in soils can occur due to organic material originated by diverse flora and fauna, such as earthworms or decaying plant roots. Earthworm casts were found with increased $\mathrm{pH}$ values in acidic soils (Tiunov et al. 2001; Horn et al. 2003), and characterized with higher contents of available nutrients, as nitrate and ammonia (Parkin and Berry 1999), or available phosphate, sulfur, enzyme activity and microbial biomass (Athmann et al. 2017). These advantageous properties were also found in root pores, but with lower contents or different microbial communities compared to worm pore, yet higher contents and activities than in bulk soil (Athmann et al. 2017). It can be suggested that the form of the nitrogen influences the metabolic activity of crop species in worm pores, root pores and bulk soil. Earthworm casts, older than two weeks, are reported to be enriched in nitrate (Parkin and Berry 1999), while the experimental bulk soil in this study contains clay minerals with non-exchangeable ammonia. For instance, nitrate leads to physiological alkalization in the rhizosphere and non-exchangeable ammonia to acidification. The chosen crop species in the current study have diverse strategies to acquire nitrogen. Faba bean is nitrogen independent since $\mathrm{N}_{2}$-fixing-symbiosis is established, whereas oilseed rape can mobilize, e.g. non-exchangeable ammonia more successfully by acidification than barley, due to a higher potassiumion uptake and proton release (Beuters et al. 2014).

Beyond that, non-invasive techniques with $\mathrm{pH}$ sensitive planar optodes have previously been reported as having been successfully deployed for observing $\mathrm{pH}$ alteration in the rhizosphere on single roots of an individual (e.g. Blossfeld et al. 2013; RudolphMohr et al. 2017). It is possible to quantify the proton-fluxes via colored $\mathrm{pH}$ indicator precisely with a relative error of $0.03 \mathrm{pH}$ units (Jaillard et al. 1996). Also mapping differences in $\mathrm{pH}$ value along root axis and the influence of the form of $\mathrm{N}$ on the proton release were shown (Plassard et al. 1999), as well as the exchange of macro- and trace elements in flooded rise land (Williams et al. 2014). Yet, to the author's knowledge, there are scarcely articles, where $\mathrm{pH}$ sensitive planar optodes were performed in a root-soil interaction experiment with several treatments and replicates and there is no study focused on structured 
subsoil of arable field. For instance, a related main experiment was performed by Kreuzeder et al. (2018), who observed the $\mathrm{pH}$ change induced by wheat, buckwheat and lupine after ammonia or nitrate supply in a calcareous and non-calcareous soil. A recent article using such technique showed in a main experiment the spatial heterogeneity along roots of lupine from apical to basal in case of $\mathrm{P}$ mobilization accompanying different $\mathrm{pH}$ values (Ma et al. 2021). Other related studies using $\mathrm{pH}$ sensitive planar optodes observing burrow walls were however carried out in marine sediment (Hulth et al. 2002; Stahl et al. 2006).

Considering this, the current study focuses on measuring dynamic $\mathrm{pH}$ changes induced by root activity of three crop species. It is assumed that the roots, in turn, are influenced by biologically formed soil structures, which is in this study related to biopores formed by taproot or earthworm. It is hypothesized, that roots of spring barley, spring oilseed rape and faba bean i) induce $\mathrm{pH}$ change in biopore sheaths, and ii) a higher $\mathrm{pH}$ change is expected for the worm than for the root biopore sheath and bulk soil.

\section{Material and methods}

\section{Experimental design}

For each of the three species, spring barley (Hordeum vulgare L.), spring oilseed rape (Bassica napus L.) and faba bean (Vicia faba L.), the following three treatments were tested: (1) "Worm type biopore": column with one worm pore formed by anecic earthworm (Lumbricus terrestris L.), (2) "Root type biopore": column with one root pore formed by chicory (Cichorium intybus L.), and (3) "Bulk soil": column with subsoil without a pore.

Per treatment four columns as replicates were prepared, a total of 36 columns were randomized together, resulting in a completely randomized design. The preparation of the soil columns in brief: plastic pipe columns (diameter $10 \mathrm{~cm}$, height $50 \mathrm{~cm}$ ) were filled and repacked (soil density $1.5 \mathrm{~g} \mathrm{~cm}^{-3}$ ) with air-dried, sieved $(<2 \mathrm{~mm})$ and homogenized subsoil of a haplic luvisol (see below). In the center of each column of treatment (1) and (2) a pore with a diameter of $6 \mathrm{~mm}$ was formed with an iron rod. Then one adult earthworm was inserted and removed after two months. For the root type biopore one seedling

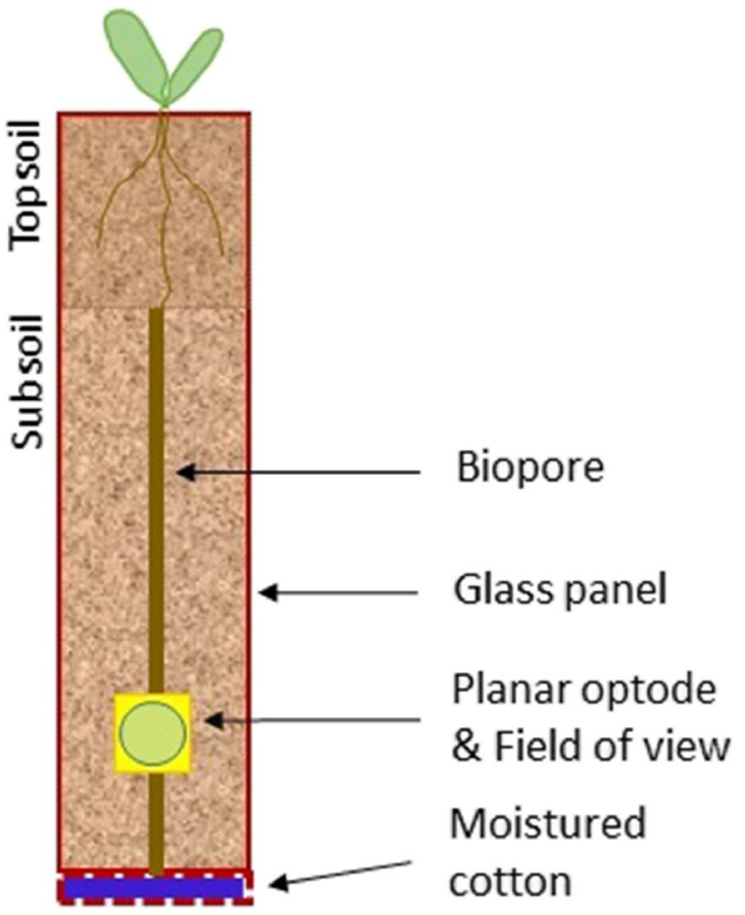

Fig. 1 Example of the rhizotrone, as a sketch

of chicory was planted as precrop and cultivated for three months. The decaying time lasted ten months and large portions of the taproot were removed from the pore before main crop cultivation (further details in Petzoldt and Kautz 2021). Before the main cultivation started, the rhizotrones were built by cutting the subsoil columns vertically into a $40 \mathrm{~cm}$ high section. The rhizotrone was built with a subsoil layer of 30 $\mathrm{cm}$ and above a topsoil layer of $10 \mathrm{~cm}$ (Fig. 1). The experimental soil texture of the topsoil is classified as silty loam with $15-20 \%$ clay, $74-77 \%$ silt and 5-8\% sand and the subsoil as silty clay with $25-30 \%$ clay, $65-70 \%$ silt and $4-5 \%$ sand (details of the reference soil profile in Pätzold et al. 2006). A vertical half was tightly sealed with a plexiglas panel with a $\mathrm{pH}$ sensitive planar optode (Type SF-HP5R, PreSens, Regensburg, Germany) at the inside. The optode was placed at a soil depth of 30-34 $\mathrm{cm}$ at time of sowing the main crops (Fig. 1). The plexiglas side was darkened with a fleece, tightened with armor tape at the sides, and three iron clamps per column. The main crop cultivation lasted from the $16^{\text {th }}$ of March to the $5^{\text {th }}$ of May 2019. Thus, germinated spring barley 'Barke', spring oilseed rape 'Ability' and faba bean 'Fanfare' were 
cultivated for seven weeks. During the cultivation, the glass faced columns were mounted at an angle of $20^{\circ}$ to allow root growth at the soil-glass interface. The rhizotrones were irrigated with deionized water daily from the top and once a week from the bottom. Therefore the bottom was kept closed with a plastic cap within a moist layer of cotton. When the experiment was finished, spring oilseed rape was in developmental code (DC) 15-17, spring barley in DC 39-50 and faba bean in DC 50-60 (Meier et al. 2009).

The planar optode had a size of $4 \times 4 \mathrm{~cm}$ and the measurement field of view amounted $3.5 \times 3.2 \mathrm{~cm}$. Fluorescent molecules were embedded in the planar optode, emitting a characteristic pattern of red, green and blue light. The ratiometric approach allows the detection of changes in the ratio between green and red color ( $\mathrm{R}$ values) caused by acidification or alkalization. The variation is detectable by a detector camera (Principle of this planar optode technique, e.g. Blossfeld and Gansert 2007; Blossfeld et al. 2013). Their $\mathrm{pH}$ range was 5.5-7.5. The planar optodes had been soaked and equilibrated in a buffer solution for 4 $\mathrm{h}$ before fixation at the plexiglas.

\section{Calibration}

A calibration was done in the experimental set-up at the beginning and the end of the experiment by using a specific tool called "CaliPlate" (PreSens, Regensburg, Germany), which contains the SF-HP5R sensor foils in a 10-well plate. Six wells were filled with a buffer solution of different $\mathrm{pH}$ values from 4.5 to 9. Two stock solutions of phosphate buffers with a buffer capacity of $40 \mathrm{mM}$ and an ionic strength of $140 \mathrm{mM}$ were used for the calibration: Solution A: $5.5 \mathrm{~g} \mathrm{NaH}_{2} \mathrm{PO}_{4} * \mathrm{H}_{2} \mathrm{O}+5.8 \mathrm{~g} \mathrm{NaCl}$, Solution B: 7.1 $\mathrm{g} \mathrm{Na}_{2} \mathrm{HPO}_{4} * 2 \mathrm{H}_{2} \mathrm{O}+1.2 \mathrm{~g} \mathrm{NaCl}$. The buffer solutions were prepared by mixing different volumes of the stock solutions.

\section{Determination of $\mathrm{pH}$ values}

The columns were controlled daily, and if it was apparent that a root had grown into the field of view, measurements were taken with a 2D-detector unit USB-Microscope device (PreSens, Regensburg, Germany) with $470 \mathrm{~nm}$ wavelength LED light, an exposure time of $0.2 \mathrm{~ms}$ and the fluorescence images had

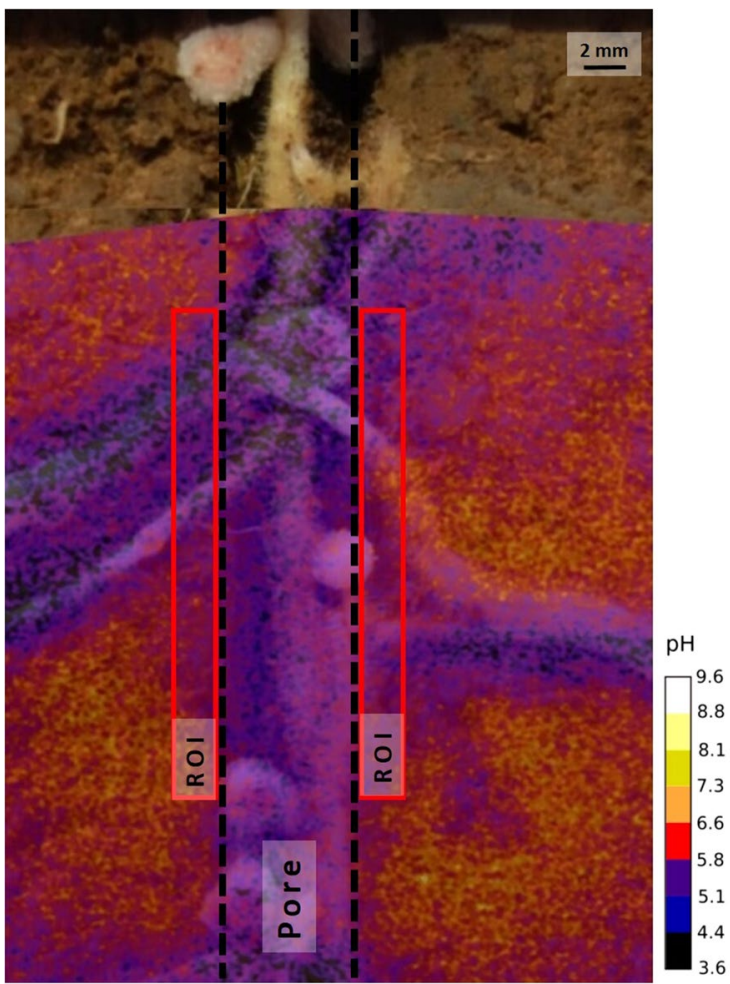

Fig. 2 Determination of $\mathrm{pH}$ value in 0-2 $\mathrm{mm}$ lateral distance from biopore, based on a photograph overlaid with a $\mathrm{pH}$ map. The $\mathrm{pH}$ values from both regions of interest (ROI) - left and right - were averaged; dashed-lined area = pore with faba bean roots and nodules

a resolution of $0.2 \mathrm{~mm}$ per pixel. The microscope is sensitive within the emission range of the optode. The measurements were calibrated with the imaging software VisiSens AnalytiCal VA 2.11 (PreSens, Regensburg, Germany). The calibrated images were further processed with the open source software Fiji, Image J (Schindelin et al. 2012). All measurements of a rhizotrone were bound into a stack, so that the regions of interest (ROI) had a defined size $(20 \times 2 \mathrm{~mm})$ besides the pore (Figure 2), and were fitted to the pore diameter. The pore diameters ranged between 6 and 10 $\mathrm{mm}$. The $\mathrm{pH}$ value was determined as the mean value from 2 consecutive measurements within $10 \mathrm{~min}-$ utes. ROI's were defined, because roots especially of spring barley and oilseed rape were usually not visible through the planar optode during the experiment. Differences in $\mathrm{pH}$ values were determined as mean values with parts of roots, rhizosphere and soil. However, visual inspection of the area behind the 
planar optode after the experiment revealed, that a ROI devoid of roots rarely occurred.

\section{Determination of total C- and N-content}

After finishing the $\mathrm{pH}$ measurements, soil samples were taken in a soil depth of $25-35 \mathrm{~cm}$ in three lateral distances from pore surface: $0-2,2-4$ and $4-8 \mathrm{~mm}$ for analyzing the total content of $\mathrm{C}$ and $\mathrm{N}\left(\mathrm{C}_{\mathrm{t}}, \mathrm{N}_{\mathrm{t}}\right)$. The scraping sampling device and the proceeding of the samples, as well as the measurement of the elements are described in detail in Petzoldt et al. 2020.

\section{Statistical analysis}

The three treatments were evaluated at the same number of days after a root appeared behind the planar optode as "Day after root entry (DAE)", separately for each species. The root entry was completed when $\operatorname{root}(\mathrm{s})$ were grown into the field of view.

First, the treatments were compared in the number of days until first root appearance behind the planar optode within the field of view (DAE=0), using a one-factorial model with pore type as fixed treatment factor. The same procedure was done to compare the $\mathrm{pH}$ values of the treatments at $\mathrm{DAE}=0$, without separating the species to refer to the treatment effect.

The main focus was on measuring the intensity $(\Delta \mathrm{pH})$ of the metabolic activity of the plants. The change in $\mathrm{pH}(\Delta \mathrm{pH})$ was calculated as difference between the $\mathrm{pH}$ value of a subsequent point in time to the $\mathrm{pH}$ value on $\mathrm{DAE}=0$ (first appearance of the root). The calculated $\Delta \mathrm{pH}$ were related to the following time intervals: 1-2, 3-4, 5-9, 10-14, 15-19 day after root entry. For the analysis of $\Delta \mathrm{pH}$, we used a mixed model for split-plot design with pore type as fixed treatment factor and DAE as fixed repeated factor. The rhizotrones served as whole plot for the repeated measurements in time, this resulted in an additional random error term (pore type x column) for wholeplot. For faba bean and barley, heterogeneous variances for DAE were additionally considered due to better model fit. Since our greenhouse did not allow precise temperature control, the temperature at the time of a $\mathrm{pH}$ measurement was included in the model as a co-factor (temperature range: $26 \pm 5{ }^{\circ} \mathrm{C}$ ), with the result of no statistical effect on $\Delta \mathrm{pH}$ response.

The $\mathrm{C}_{\mathrm{t}^{-}}$and $\mathrm{N}_{\mathrm{t}}$-content were analyzed, separately for species, using a mixed model for split-plot design with pore type and lateral distance (0-2, 2-4 and 4-8 $\mathrm{mm}$ ) from each macropore as two fixed treatment factors. The rhizotrones served as whole plot for the lateral measurements leading to pore type $\mathrm{x}$ column effect as additional random whole plot error term.

Pairwise comparisons between Least Square Means were made by t-Test with Bonferroni correction to account for the multiple testing situation $(\alpha=0.05)$. Statistical analysis was performed using MIXED procedures by SAS 9.4 software (SAS Institute Inc., Cary, NC, USA). The figures were done using the software package Microsoft Office 2013 (Microsoft Cooperation, Redmond, WA, USA).

\section{Results}

Root growth, nodulation, pore diameter and initial $\mathrm{pH}$ value

The roots of faba bean reached the field of view first in pots with worm pores, followed by pots with root pores and bulk soil (Figure 3a). The diameter of the worm pore was significantly larger than the root pore, however both pores were several times larger than the root diameters (Figure 3a, Supplement 1). Overall, at the time, when spring oilseed rape reached the planar optode, a comparatively fast root growth with the formation of plenty of roots was observed. That resulted in a comparatively small number of measurements. In the case of the bulk soil treatment in faba bean less measurements were taken due to delayed root growth until the experiment had to be stopped.

The average root diameter of spring oilseed rape (range: 0.19-0.37 mm) and faba bean (range: 0.39$0.60 \mathrm{~mm}$ ) did not differ between the treatments, as well as between the biopore and biopore sheath in the worm or root type treatment (Supplement 1; no data available for spring barley).

In faba bean there was a significantly higher nodulation in the topsoil than in subsoil in worm type and bulk soil treatment, which was equal in root type treatment (Supplement 2). At the end of the experiment the number of nodules pot $^{-1}$ in the field of view was $5.00 \pm 1.21$ (LS-Mean \pm SEM) in root type, $0.75 \pm 1.21$ in worm type and $0 \pm 0$ in bulk soil treatment.

The $\mathrm{pH}$ value of the treatment at time of the first measurement $(\mathrm{DAE}=0)$ were decreasing in the 

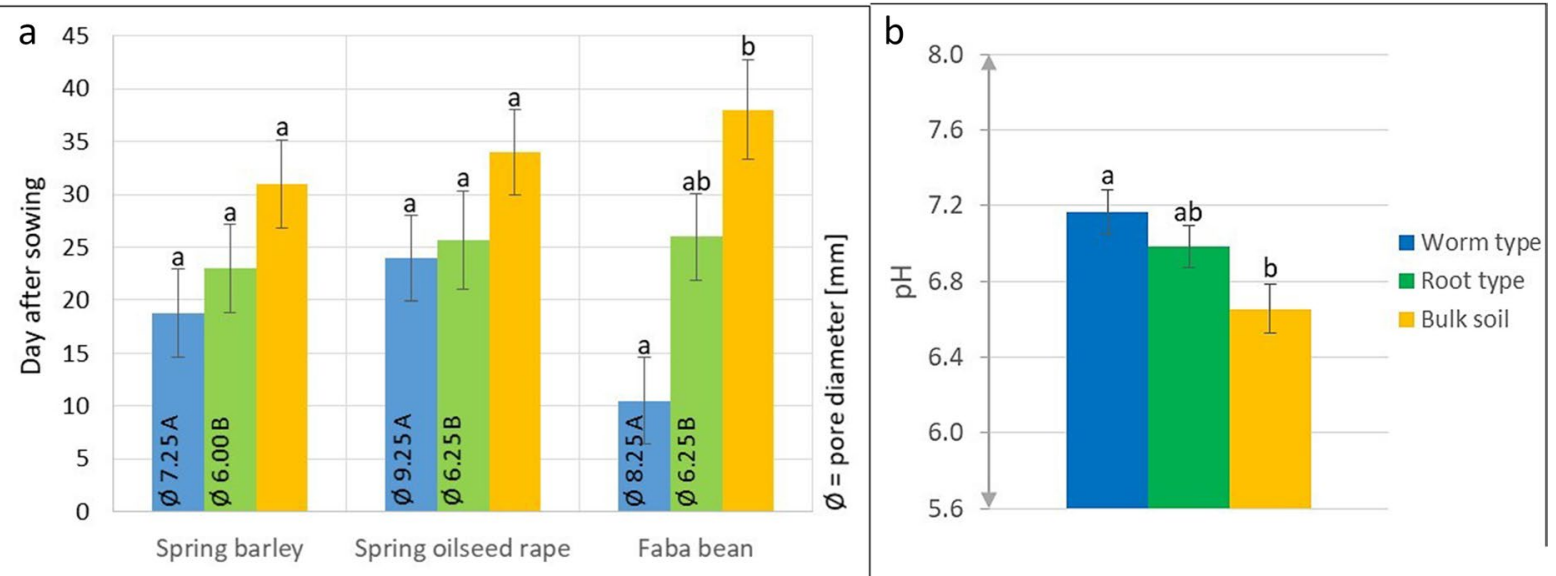

Fig. 3 a: Days until root entry into the field of view and pore diameter $[\mathrm{mm}]$, separately by the species spring barley, spring oilseed rape and faba bean in worm (blue) or root (green) type biopore and bulk soil (yellow). LS-Mean \pm SEM, $n=4$, t-test with Bonferroni-correction, $\alpha=0.05$; lowercase (root entry day) and uppercase (pore diameter) letters show differences if they

following order: worm biopore sheath $(\mathrm{pH} 7.16)>$ root biopore sheath $(\mathrm{pH}$ 6.99) $>$ bulk soil $(\mathrm{pH}$ 6.61) with a significant difference between worm type and bulk soil (Figure 3b).

\section{Metabolic activity as indicated by $\mathrm{pH}$ change}

In spring barley, the $\Delta \mathrm{pH}$ varied between -0.19 and +0.32 in the bulk soil, -0.10 and +0.01 in worm type pore and +0.05 and +0.29 in root type pore (Figure 4). In spring oilseed rape, the $\Delta \mathrm{pH}$ raised in root pore from time interval 1-2 to 5-9 DAE with 0.67 unit ( $\mathrm{p}$-value $=0.062$ ). In the bulk soil a significant increase was found since time interval 1-2 to 5-9 DAE with $0.80 \mathrm{pH}$ unit. While in worm pore sheath a maximum was reached at the time interval 1-2 DAE with $0.22 \Delta \mathrm{pH}$. In faba bean, a significant difference was found in root type treatment over time from the time interval 1-2 to 15-19 DAE, with a strong decrease of -0.95 until 10-14 DAE or $-1.05 \Delta \mathrm{pH}$ unit until 15-19 DAE. In worm biopore sheath the $\mathrm{pH}$ change reached its maximum in $0.33 \Delta \mathrm{pH}$ at time interval 3-4 DAE and in bulk soil with $0.29 \Delta \mathrm{pH}$ at time interval $1-2$ DAE. In the three crops, the $\Delta \mathrm{pH}$ was comparatively small in the worm pore sheath, whereas in root pore sheath and bulk soil higher $\Delta \mathrm{pH}$ were found. The observed $\mathrm{pH}$ values for all measuring days can be found in Supplement 3. have no letter in common, Figure $3 \mathrm{~b}: \mathrm{pH}$ value at time of the first measurement(DAE $=0$ ) averaged over all crops in worm (blue) or root (green) type biopore sheath $(0-2 \mathrm{~mm}$ lateral distance) and bulk soil (yellow). LS-Mean \pm SEM, $n=12$, t-test with Bonferroni-correction, $\alpha=0.05$; least-square means show differences if they have no letter in common

$\mathrm{C}_{\mathrm{t}}$ - and $\mathrm{N}_{\mathrm{t}}$-content in the biopore sheath

For spring oilseed rape and faba bean the $\mathrm{C}_{\mathrm{t}}$ - and $\mathrm{N}_{\mathrm{t}}$-content in the biopore sheath of different lateral distances were measured (Figure 5). A significantly higher $\mathrm{C}_{\mathrm{t}}$-content was found in $0-2 \mathrm{~mm}$ than in 4-8 $\mathrm{mm}$ lateral distance from macropore in the worm type sheath in spring oilseed rape. In faba bean a significant increase was found in the $\mathrm{C}_{\mathrm{t}^{-}}$and $\mathrm{N}_{\mathrm{t}}$-content in worm type sheath of 0-2 $\mathrm{mm}$. No differences were found in root type sheath for both elements and crops. Data for spring barley is not available.

\section{Discussion}

Roots of an individual plant grow through different structures along a soil profile with temporal and spatial heterogeneity. While growing they adapt the growing path, e.g. due to nutrient attraction or to bypass physical impedance (e.g. Correa et al. 2019). In the current study faster root growth, in terms of reaching the planar optode, was observed for worm than for root type pore and least for bulk soil, particularly in faba bean. Faster root growth through biopores, also reported by Gaiser et al. (2013), especially during dry spells (Gaiser et al. 2012) can be facilitated by unimpeded physical access pathway 


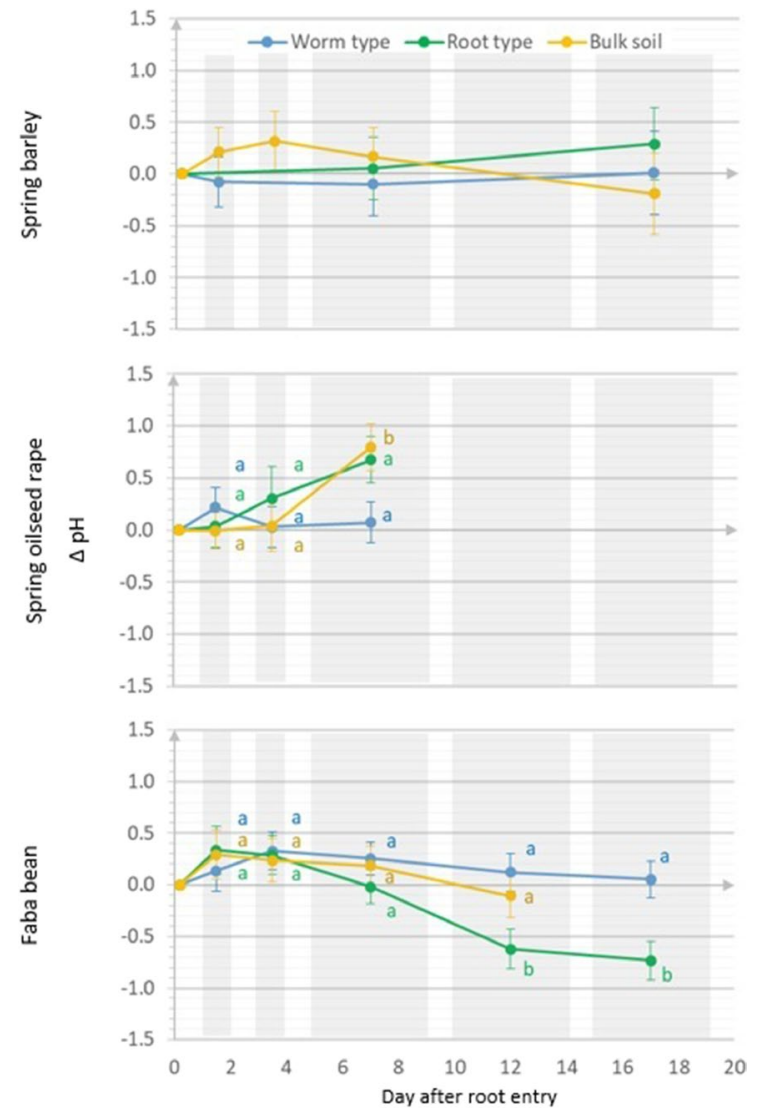

Fig. $4 \mathrm{pH}$ change due to root growth of spring barley, spring oilseed rape and faba bean in worm (blue) or root (green) type biopore sheath and bulk soil (yellow). The change in $\mathrm{pH}$ $(\Delta \mathrm{pH})$ was calculated as difference between the $\mathrm{pH}$ value of a subsequent point in time to the $\mathrm{pH}$ value on "Day after root entry" $=0$ (first appearance of the root). LS-Mean \pm SEM of the time intervals: 1-2, 3-4, 5-9, 10-14, 15-19 day after root entry and t-test with Bonferroni-correction, $\alpha=0.05$; least-square means of a treatment show differences between the time intervals if they have no letter in common

(Ehlers et al. 1983; McKenzie et al. 2009). Even if large-sized biopore allowed for unimpeded root elongation, there was still a comparatively high variance between the individuals, which pointed out the heterogeneous nature of root growth. Moreover, in this experiment faba bean roots were comparatively early in time and highly present in the biopores, which is contrary to other results (Athmann et al. 2019a; Petzoldt and Kautz 2021). That can be caused by the inclined position of the rhizotrone, the placement of the seedling above the pore and faba as a species, which was found to have less root plasticity than graminaceous species
(Li et al. 2014). In addition, for the bulk soil, it cannot be ruled out that the construction of the rhizotrones had an influence on the delayed root growth, since thickened faba bean roots were observed partwise. However, there was no significant difference in the average root diameter between the treatments (Supplement 1). Contrary to faba bean, there were no significant differences in the elongation rate between biopores and bulk soil in spring oilseed rape, even though oilseed rape showed an attraction to biopores in a previous study (Athmann et al. 2019a). This could also be caused by the rhizotrone, due to small spaces between the bulk soil and plexiglas, which could have influenced the root growth in the bulk soil treatment. However, it appeared that roots were more attracted by worm than by root type biopores. This can be a result of the larger sized worm pores and the highly available nutrients in earthworm casts, rather than in root debris or bulk soil (Athmann et al. 2017). Hence, biopores, particularly coated with worm linings, supported faster root elongation towards deeper soil layers with the potential of a more rapid access to resources in the subsoil.

Comparatively higher microbial activity and nutrient availabilities for worm pore sheath, but also for root pore sheath in comparison to bulk soil (Athmann et al. 2017) was considered facilitating higher metabolic activity, as observed by $\mathrm{pH}$ change as indicator. However, in all three crops in the worm type sheath the $\mathrm{pH}$ value varied at the slight alkaline $\mathrm{pH}$ range within the first 20 days after root entry, without distinct effects in alteration over time. Although, in the root type and bulk soil treatment the intensity of the metabolic activity differed between the three experimental crop species. Homorhizous spring barley showed slight $\mathrm{pH}$ changes in the biopore sheaths and bulk soil, whereas both allorhizous crops showed a distinct $\mathrm{pH}$ change in root type sheath, as well as spring oilseed rape in the bulk soil. This can be due to a higher ability of oilseed rape and faba bean to alter the $\mathrm{pH}$ value (Beuters et al. 2014; Schubert et al. 1990). In spring oilseed rape an alkalization effect over time was found in root pore sheath and bulk soil, which had a neutral to slightly acidic initial $\mathrm{pH}$ value. While faba bean showed the same pattern of $\mathrm{pH}$ change in all treatments until day 9 after root entry. Thus, young faba bean roots slightly increased the $\mathrm{pH}$ value until day 4 after root entry followed by 

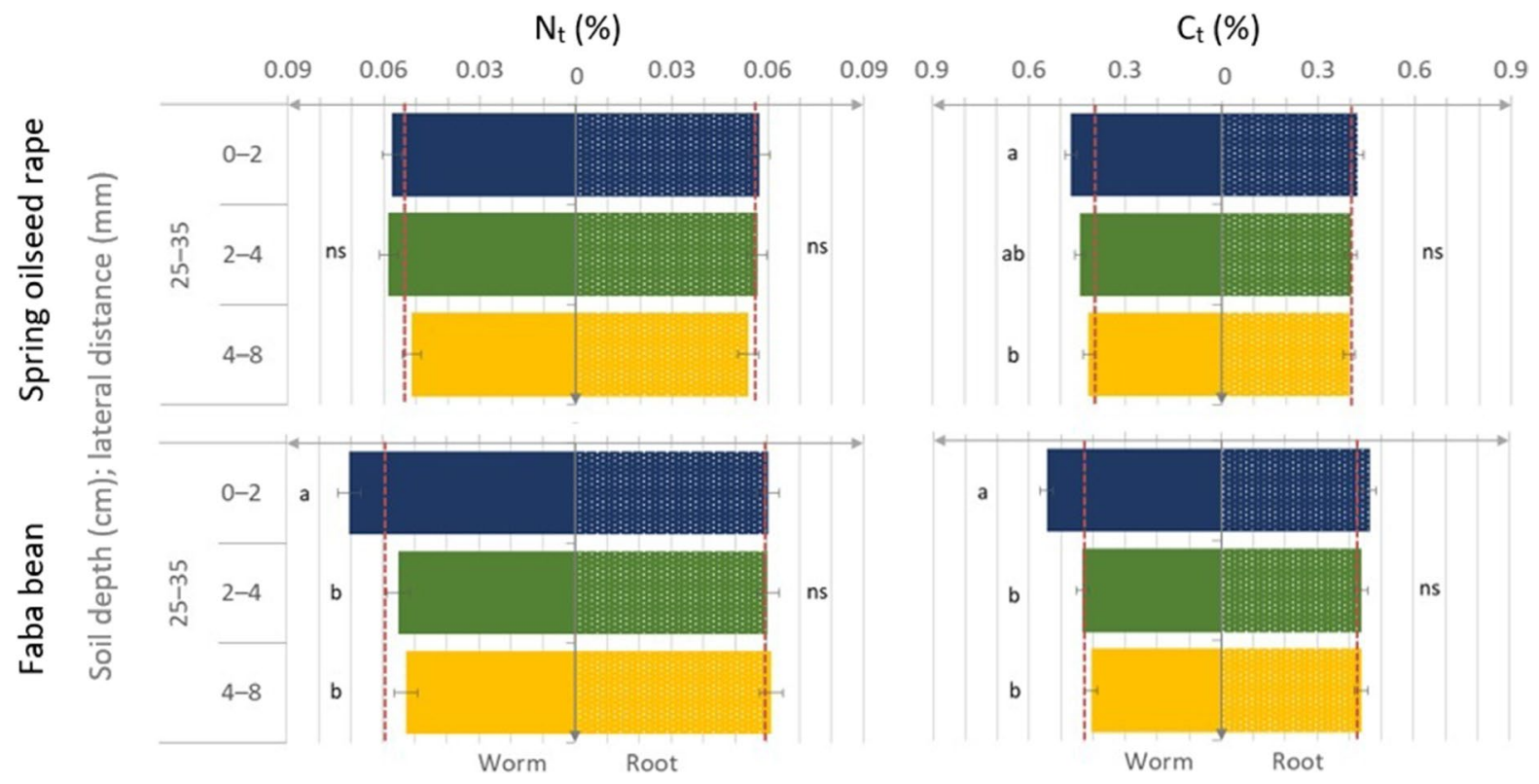

Fig. $5 \mathrm{C}_{\mathrm{t}}$ - and $\mathrm{N}_{\mathrm{t}}$-content in the biopore sheath in spring oilseed rape and faba bean. Lowercase letter show significant differences if there is no letter in common between lateral distances within the respective biopore type "Worm" (left)

a decrease. The same pattern of the $\mathrm{pH}$ change of first slightly increasing and then decreasing, was previously found for white clover (Marschner et al. 1986). The decrease was particularly found for root type biopore with a strong acidifying effect since day 9 after root entry. At that time nodulation in root type biopore in the field of view occurred. Presumably, less nodulation in worm than in root type pore can be caused by a higher nitrate content in worm type sheath, because higher nitrate contents were found to inhibit the formation of the infection tube (Munns 1968). However, it is apparent that the roots showed activity when growing through the biopore sheaths. Even though $\mathrm{pH}$ alteration in the worm biopore sheath was less intensive than in root type sheath and bulk soil. Moreover, homorhizous spring barley showed overall no distinct effects in the ability to alter the $\mathrm{pH}$ value, conversely to both allorhizous crops.

Root activity is influenced by the source of nutrients (Marschner et al. 1986), the soil's buffer capacity and initial $\mathrm{pH}$ value (Nye 1981; Schubert et al. 1990; Kreuzeder et al. 2018). Earthworm linings were reported to have increased $\mathrm{pH}$ values in comparison to the bulk soil (Tiunov et al. 2001; Horn et al. 2003) and increased nitrate contents (Parkin and Berry and "Root" (right), the red dashed line shows the value of the bulk soil treatment, t-test with Bonferroni-correction, $\alpha=0.05$, $\mathrm{ns}=$ not significant

1999). Nitrate or ammonia nutrition led to a physiologic acidic or alkaline response dependent on the initial soil pH value (Kreuzeder et al. 2018). In the current study the earthworm's modification of the inner layer of the biopore sheath led to a higher initial $\mathrm{pH}$ value $(\mathrm{pH} 7.16)$, higher $\mathrm{C}_{\mathrm{t}^{-}}$and $\mathrm{N}_{\mathrm{t}}$-contents, except $\mathrm{N}_{\mathrm{t}}$-content in spring oilseed rape, and moderate $\mathrm{pH}$ changes induced through the roots. These results of the $\mathrm{C}_{\mathrm{t}}$ - and $\mathrm{N}_{\mathrm{t}}$-contents analysed at the end of the experiment might indicate an $\mathrm{N}$-uptake at the inner layer of the sheath of spring oilseed rape. However, the comparatively moderate metabolic activity in worm type sheath can be assumed as an effect of i) higher nutrient availabilities, which resulted in less root activity, or ii) a less measurable $\mathrm{pH}$ change of the planar optodes caused by a higher buffering capacity (Mengel 1991; Hinsinger et al. 2003). A higher buffering capacity was found in earthworm casts due to an increasing calcite-content (Lambkin et al. 2011). Although, in a recent study with $\mathrm{pH}$ sensitive planar optodes a higher $\mathrm{P}$ availability lead to less acidification in the rhizosphere of maize and lupine (Ma et al. 2021), which would be in alignment with the assumption of less activity due to highly available nutrients in earthworm casts. Instead, in the root type sheath 
no distinct enrichment with $\mathrm{C}_{t}$ and $\mathrm{N}_{t}$ was found, which was contrary to a former study (Petzoldt and Kautz 2021). In the current study, this could be due to removing the scarcely decayed taproot of the precrop before the experiment started. The $\mathrm{N}$-content of the root type sheath was not different to the bulk soil, but small effects of root deposits or debris left from the precrop are likely. That was indicated by a slightly higher initial $\mathrm{pH}$ value ( $\mathrm{pH}$ 6.99) in comparison to the bulk soil ( $\mathrm{pH}$ 6.61) and the observed appreciable $\mathrm{pH}$ change in spring oilseed rape and faba bean. A higher initial $\mathrm{pH}$ value in the worm type than root type sheath is in line with results from the same experimental soil (Haas and Horn 2018). The earthworm and precrop treatment modified initial chemical conditions at the inner layer of the biopore sheath. That presumably resulted in less observable effects in the earthworm treatment with this method or less activity due to a higher availability of nutrients. The use of $\mathrm{pH}$ sensitive planar optodes for comparative observations of the metabolic activity of roots in environments with different initial $\mathrm{pH}$ values are clearly limited.

Overall, high variations of the $\mathrm{pH}$ value within the treatments were found (Fig. 4), which can be a result of (in)active roots, root orders and root maturity over time. Other studies using $\mathrm{pH}$ planar optode techniques showed, that metabolic activity changed in response to the form of phosphor (Ma et al. 2021), nitrogen and initial $\mathrm{pH}$ value (Kreuzeder et al. 2018), but also by root aging and differentiation (Blossfeld et al. 2013; Rudolph et al. 2013; Rudolph-Mohr et al. 2017). Complementary observations were made for temporal, permanent (Blossfeld et al. 2010) or diurnal (Blossfeld et al. 2011) differences in the metabolic activity. Our study reveals that structured subsoil contribute to the large temporal and spacial variation of root activity in the subsoil.

\section{Conclusions}

The methodological approach with $\mathrm{pH}$ sensitive planar optodes made it possible to measure root activity in the biopore sheath. However, earthworms' modification of the chemical properties resulted in less $\mathrm{pH}$ change, which might not be necessarily a result of less root activity and would need additional investigation. Our hypothesis, that roots induce $\mathrm{pH}$ change in biopore sheaths was confirmed for oilseed rape and faba been. This clearly indicates that biopores are not only preferential pathways for root growth but also hotspots of root activity. Higher $\mathrm{pH}$ changes around roots in worm pores were not confirmed which was probably caused by increased buffer capacity in the worm pore sheath. In conclusion, faster root growth of spring crops through deeper untilled soil layers was facilitated by biopores. Such a beneficial effect can be increased by nutrient uptake at the biopore sheath especially in periods with increased drought.

Acknowledgements The authors are grateful to the technical support by Johannes Siebigteroth (Experimental Station Wiesengut, University of Bonn, Germany), Dr. Daniela Obermaier (PreSens, Regensburg, Germany), Ina Vogel, and by the support of the student Maike Apel.

Funding Open Access funding enabled and organized by Projekt DEAL. This research was funded by the German Research Foundation (Deutsche Forschungsgemeinschaft - DFG) within the DFG project KA2703/3-1.

\section{Declarations}

Conflicts of Interest The authors declare that they have no conflict of interest.

Open Access This article is licensed under a Creative Commons Attribution 4.0 International License, which permits use, sharing, adaptation, distribution and reproduction in any medium or format, as long as you give appropriate credit to the original author(s) and the source, provide a link to the Creative Commons licence, and indicate if changes were made. The images or other third party material in this article are included in the article's Creative Commons licence, unless indicated otherwise in a credit line to the material. If material is not included in the article's Creative Commons licence and your intended use is not permitted by statutory regulation or exceeds the permitted use, you will need to obtain permission directly from the copyright holder. To view a copy of this licence, visit http://creativecommons.org/licenses/by/4.0/.

\section{References}

Athmann M, Beuters P, Küppers PM, Kautz T, Köpke U (2016) Quantifying N uptake from the subsoil: A biopore labelling field approach. Geophysical Research Abstracts Vol. 18, EGU2016-6186:1.

Athmann M, Kautz T, Banfield C, Bauke S, Hoang DTT, Lüsebrink M, Pausch J, Amelung W, Kuzyakov Y, Köpke U (2017) Six months of L. terrestris L. activity in rootformed biopores increases nutrient availability, microbial biomass and enzyme activity. Applied Soil Ecology 120:135-142 
Athmann M, Sondermann J, Kautz T, Köpke U (2019a) Comparing Macropore Exploration by Faba Bean, Wheat, Barley and Oilseed Rape Roots Using In Situ Endoscopy. Journal of Soil Science and Plant Nutrition 19:689-700

Athmann M, Kautz T, Köpke U (2019b) Wurzelwachstum und Nodulation von Luzerne: Einfluss von Bioporendichte im Unterboden und Nährstoffgehalt im Oberboden. In: Mühlrath, D., Albrecht, J., Finckh, M. R., Hamm, U., Heß, J., Knierim, U., Möller, D. (Hrsg.) Innovatives Denken für eine nachhaltige Land- und Ernährungswirtschaft. Beiträge zur 15. Wissenschaftstagung Ökologischer Landbau, Kassel, 5. bis 8. März 2019, Verlag Dr. Köster, Berlin.

Beuters P, Eichert T, Scherer HW (2014) Influence of precrop and root architecture on the mobilization of nonexchangeable $\mathrm{NH}_{4}{ }^{+}$. Plant Soil Environ. 60:372-378

Blossfeld S, Gansert D (2007) A novel non-invasive optical method for quantitative visualization of $\mathrm{pH}$ dynamics in the rhizosphere of plants. Plant, Cell \& Environment 30:176-186

Blossfeld S, Perriguey J, Sterckeman T, Morel J-L, Lösch R (2010) Rhizosphere pH dynamics in trace-metal-contaminated soils, monitored with planar $\mathrm{pH}$ optodes. Plant and Soil 330(1):173-184

Blossfeld S, Gansert D, Thiele B, Kuhn AJ, Lösch R (2011) The dynamics of oxygen concentration, $\mathrm{pH}$ value, and organic acids in the rhizosphere of Juncus spp. Soil Biology and Biochemistry 43(6):1186-1197

Blossfeld S, Schreiber CM, Liebsch G, Kuhn AJ, Hinsinger P (2013) Quantitative imaging of rhizosphere $\mathrm{pH}$ and $\mathrm{CO}_{2}$ dynamics with planar optodes. Ann Bot 112:267-276

Correa J, Postma JA, Watt M, Wojciechowski T (2019) Soil compaction and the architectural plasticity of root systems. J Exp Bot 70(21):6019-6034

Ehlers W, Köpke U, Hesse F, Böhm W (1983) Penetration resistance and root growth of Oats in tilled and untilled Loess soil. Soil and Tillage Research 3:261-275

Gaiser T, Perkons U, Küpper PM, Uteau Puschmann D, Peth S, Kautz T, Pfeifer J, Ewert F, Horn R, Köpke U (2012) Evidence of improved water uptake from subsoil by spring wheat following lucerne in a temperate humid climate. Field Crops Research 126:56-62

Gaiser T, Perkons U, Küpper PM, Kautz T, UteauPuschmann D, Ewert F, Enders A, Krauss G (2013) Modeling biopore effects on root growth and biomass production on soils with pronounced sub-soil clay accumulation. Ecological Modelling 256:6-15

Haas C, Horn R (2018) Impact of small-scaled differences in micro-aggregation on physico-chemical parameters of macroscopic biopore walls. Frontiers in Environmental Science 6:90

Hinsinger P, Plassard C, Tang C, Jaillard B (2003) Origins of root-mediated $\mathrm{pH}$ changes in the rhizosphere and their responses to environmental constraints: A review. Plant and Soil 248:43-59

Hinsinger P, Bengough AG, Vetterlein D, Young IM (2009) Rhizosphere: biophysics, biogeochemistry and ecological relevance. Plant and Soil 321:117-152

Hodge A, Berta G, Doussan C, Merchan F, Crespi M (2009) Plant root growth, architecture and function. Plant Soil 321(153-187):153-187
Horn MA, Schramm A, Drake HL (2003) The earthworm gut: an ideal habitat for ingested $\mathrm{N}_{2} \mathrm{O}$-producing microorganisms. Appl Environ Microbiol 69:1662-1669

Hulth S, Aller RC, Engstrom P, Selander E (2002) A pH plate fluorosensor (optode) for early diagenetic studies of marine sediments. Limnol Oceanogr 47:212-220

Jaillard B, Ruiz L, Arvieu JC (1996) pH mapping in transparent gel using color indicator videodensitometry. Plant Soil 183:85-95

Kreuzeder A, Santner J, Scharsching V, Oburger E, Hoefer C, Hann S, Wenzel WW (2018) In situ observation of localized, sub-mm scale changes of phosphorus biogeochemistry in the rhizosphere. Plant Soil 424:573-589

Kuhlmann H, Barraclough P, Weir A (1989) Utilization of mineral nitrogen in the subsoil by winter wheat. $\mathrm{Z}$. Pflanzenernaehr. Bodenk. 152:291-295

Lavelle P (1988) Earthworm activities and the soil system. Biol Fertil Soils 6:237-251

Li H, Ma Q, Li H, Zhang F, Rengel Z, Shen J (2014) Root morphological responses to localized nutrient supply differ among crop species with contrasting root traits. Plant Soil 376:151-163

Logsdon SD, Linden DR (1992) Interactions of earthworms with soil physical conditions influencing plant growth. Soil Sci. 154:330-337

Ma X, Liu Y, Shen W, Kuzyakov Y 2021. Phosphatase activity and acidification in lupin and maize rhizosphere depends on $\mathrm{P}$ availability and root properties: coupling zymography with planar optode imaging. Applied Soil Ecology 167.

Marschner H, Romheld V, Horst WJ, Martin P (1986) Rootinduced changes in the rhizosphere: Importance for the mineral nutrition of plants. Z. Pflanzenernaehr. Bodenk. 149:441-456

McKenzie BM, Bengough AG, Hallett PD, Thomas WTB, Forster B, McNicol JW (2009) Deep rooting and drought screening of cereal crops: A novel field-based method and its application. Field Crops Research 112(2-3):165-171

Meier U, Bleiholder H, Buhr L, Feller C, Hack H, Heß M, Lancashire PD, Schnock U, Stauß R, van den Boom T, Weber E, Zwerger P (2009) The BBCH system to coding the phenological growth stages of plants - history and publications. Journal für Kulturpflanzen 61(2):41-52

Mengel K (1991) Ernährung und Stoffwechsel der Pflanze. 7, überarbeitete Auflage edn. Gustav Fischer Verlag, Jena

Munns DN (1968) Medicago sativa in solution culture. III. Effects of nitrate on root hairs and infection. Plant and soil 29:33-47

Nye PH (1981) Changes of $\mathrm{pH}$ across the rhizosphere induced by roots. Plant and Soil 61:7-26

Pagenkemper SK, Athmann M, Uteau D, Kautz T, Peth S, Horn R (2015) The effect of earthworm activity on soil bioporosity - Investigated with X-ray computed tomography and endoscopy. Soil and Tillage Research 146:79-88

Parkin TB, Berry EC (1999) Microbial nitrogen transformations in earthworm burrows. Soil Biology and Biochemistry $31: 1765-1771$

Passioura JB (1991) Soil Structure and Plant Growth. Aust. J. Soil Res. 29:717-728 
Pätzold, S., Vetterlein, D., Jahn, R. 2006. DFG Research Unit 1320. Crop Sequence and the Nutrient Acquisition from the Subsoil. Description of the Reference Soil Profile. URL: https://www.cka.uni-bonn.de/standort/bodenprofi lbeschreibung-cka (Assessed 07 April 2021).

Petzoldt L, Athmann M, Buechse A, Kautz T (2020) Root Growth of Hordeum vulgare and Vicia faba in the Biopore Sheath. Agriculture 10(12):650

Petzoldt L, Kautz T (2021) Root Distribution of Brassica napus and Vicia faba within the Sheath of Root or Earthworm Biopore. Agriculture 11(1):61

Plassard C, Meslem M, Souche G, Jaillard B (1999) Localization and quantification of net fluxes of $\mathrm{H}+$ along maize roots by combined use of $\mathrm{pH}$-indicator dye videodensitometry and $\mathrm{H}^{+}$-selective microelectrodes. Plant Soil 211:29-39

Rudolph N, Voss S, Moradi AB, Nagl S, Oswald SE (2013) Spatio-temporal mapping of local soil $\mathrm{pH}$ changes induced by roots of lupin and soft-rush. Plant Soil 369(1-2):669-680

Rudolph-Mohr N, Vontobel P, Oswald SE (2014) A multiimaging approach to study the root-soil interface. Annals of Botany 114:1779-1787

Rudolph-Mohr N, Tötzke C, Kardjilov N, Oswald SE (2017) Mapping water, oxygen, and $\mathrm{pH}$ dynamics in the rhizosphere of young maize roots. Journal of Plant Nutrition and Soil Science 180:336-346

Schindelin J, Arganda-Carreras I, Frise E, Kaynig V, Longair M, Pietzsch T, Preibisch S, Rueden C, Saalfeld S, Schmid B, Tinevez JY, White DJ, Hartenstein V, Eliceiri K, Tomancak P, Cardona A (2012) Fiji: an open-source platform for biological-image analysis. Nat Methods 9:676-682

Schubert S, Schubert E, Mengel K (1990) Effect of low pH of the root medium on proton release, growth, and nutrient uptake of field beans (Vicia faba). Plant Soil 124:239-244
Stahl H, Glud A, Schröder CR, Klimant I, Tengberg A, Glud $\mathrm{RN}$ (2006) Time-resolved $\mathrm{pH}$ imaging in marine sediments with a luminescent planar optode. Limnol. Oceanogr.: Methods 4:336-345

Tiunov AV, Scheu S (1999) Microbial respiration, biomass, biovolume and nutrient status in burrow walls of Lumbricus terrestris L. (Lumbricidae). Soil Biology and Biochemistry 31:2039-2048

Tiunov AV, Bonkowski M, Alphei J, Scheu S (2001) Microflora, Protozoa and Nematoda in Lumbricus terrestris burrow walls: a laboratory experiment. Pedobiologia 45:46-60

Uksa M, Schloter M, Kautz T, Athmann M, Köpke U, Fischer D (2015) Spatial variability of hydrolytic and oxidative potential enzyme activities in different subsoil compartments. Biology and Fertility of Soils 51:517-521

Volkmar KM (1996) Effects of biopores on the growth and N'uptake of wheat at three levels of soil moisture. Canadian Journal of Soil Science:453-458

Walter A, Silk WK, Schurr U (2009) Environmental effects on spatial and temporal patterns of leaf and root growth. Annu Rev Plant Biol 60:279-304

Williams PN, Santner J, Larsen M, Lehto NJ, Oburger E, Wenzel W, Glud RN, Davison W, Zhang H (2014) Localized Flux Maxima of Arsenic, Lead, and Iron around Root Apices in Flooded Lowland Rice. Environ Sci Technol 48:8498-8506

Publisher's note Springer Nature remains neutral with regard to jurisdictional claims in published maps and institutional affiliations. 